\title{
Technological Peculiarities the Development of Watered Sand Deposits Leningrad Region
}

\author{
Vladimir Viktorovich Ivanov and Andrey Aleksandrovich Sidorenko
}

\author{
National Mineral Resources University, Vasilyevsky Island, \\ $21^{\text {st }}$ Line, 199106 Saint-Petersburg, Russia.
}

DOI: http://dx.doi.org/10.13005/bbra/1976

(Received: 10 August 2015; accepted: 18 October 2015)

\begin{abstract}
The article discusses main peculiarities of generation of alluvial, old alluvial, true glacial and fluvioglacial sand deposits and sand-and-gravel mix. Published data in the field of open method of development of flooded $f$ sand deposits have been analyzed, analytical review has been arranged on the basis of design and detailed documentation of mining companies extracting flooded sands and supplying this feedstock for companies of St. Petersburg and Leningrad Region. The main geological and hydrogeological peculiarities of occurrence and climatic conditions of development of flooded sand deposits in Tosno, Vyborg and Vsevolozhsk districts of Leningrad Region have been determined. Main methods of uncovering, development systems and major mining and handling equipment applied upon development of flooded sand deposits of Leningrad Region have been established. Main parameters of mining operations are presented with regard to extraction of alluvial sand using floating dredges as well as downward digging of flooded sands by excavator. Equations are proposed for determination of dredge productivity with accounting for dredge repositioning into a new position of extractive operations, as well as for calculation of bulk of rocks which should be extracted at one operation site of dredge.
\end{abstract}

Key words: Leningrad region, sands deposits, quarry, dredge, dragline, water content of deposit.

At present the economy of Leningrad Region is one of the most developed among the subjects of Russian Federation in the scope of Northwestern economic region of Russia.

Taking into account increased scope of construction activities in St. Petersburg, its suburbs and large cities of Leningrad Region, as well as related with erection of additional athletic facilities and infrastructure objects required for arrangement of events associated with FIFA and UEFA championships, the demands for mortar sand continuously increase. The increase in sand demand in St. Petersburg and Leningrad Region

\footnotetext{
* To whom all correspondence should be addressed.
}

leads to intensification of deposit development of this feedstock, which is accompanied with increase in mining depth of these deposits, significant reserves of this flooded material are involved in the development. In this regard there appear certain requirements to approved technological solutions , since the quality of waste water disposed into water sources adjacent to quarry, should meet regulative requirements, which also causes increased expenses for treatment of waste water.

Natural sand is a widely applied mineral, its average density (bulk weight) exceeds $2000 \mathrm{~kg} /$ $\mathrm{m}^{3}$, grain sizes vary from 0.7 to $5 \mathrm{~mm}$. This material is generated during natural destruction of rocks. Main quality properties of natural sands are grain composition (coarseness modulus), the content of dust and clay particles, including clay in aggregates. 
Sand is the most important material for building and landscaping, it is the major feedstock for road construction. In addition, sand is an important component for production of such building materials as as concrete and bricks, it is applied in civil construction, as well as in construction of industrial buildings and structures. In addition, sand is applied in sandblast processing and glass manufacturing.

Sand is extracted upon development of sand or sand and gravel deposits. About $60 \%$ of sand and sand and gravel quarries, planned for development or already operating, exist in the form of flooded reserves of the minerals. Selection of means of mechanization and development flowcharts of sand deposits are determined by the degree of water content of the developed deposits, content of gravel and boulder fractions and mining and geological conditions of deposits (Gilev, 2008).

In order to extract sand in a quarry such deposit is dewatered by means of specialized drainage, then its development is performed by open method using excavators or loaders, otherwise it is flooded for underwater production by dredges with downward digging tools.

Quarry sand and sand and gravel mix in Leningrad Region is extracted at more than 50 development sites, sea sand is extracted in Gulf of Finland. Cumulative amounts of these minerals equal to more than 20 million cu. meters per year (Peshkova, 2014).

Mining companies developing flooded sand deposits should have detailed information about mineral and petrographic characteristics of ores, grain shapes, surface properties, average density of overburden rocks and valuable mineral, content of harmful reactive minerals and ores, organic impurities, as well as hydrogeological peculiarities if the deposit occurrence.

Shape of occurrence of sand deposits is most commonly lenticular; herewith, alteration of sand layers of various grain size distribution is possible. Reserves of one deposit are in the range from 2.5 to 16 million $\mathrm{m}^{3}$. Capacity of working thickness at various sand deposits varies from 1.5 to $15 \mathrm{~m}$, capacity of cap rocks varies from 2 to $4 \mathrm{~m}$.

The thickness of cap rocks at flooded sand deposits is usually presented by the layers of sand clays, clay loams, fine grain clayish ores.

Boulder-gravel-sand, gravel-and- sand, sand-and-gravel and sand deposits are sedimentary detrital deposits, their generation is related with weathering and destruction of bed rocks, their flow, further disintegration and accumulation of the generated products. Name of the deposits is determined by existence of rocks in deposit working thickness and their percentage ratio by weight: sand (particle size up to $5 \mathrm{~mm}$ ), gravel (from 5 to $100 \mathrm{~mm}$ ), boulders (more than 100 $\mathrm{mm}$ ). In sand deposits the content of gravel grains should not exceed $10 \mathrm{wt} \%$; in sand-and-gravel deposits the content of gravel grains with the size higher than $5 \mathrm{~mm}$ should not be lower than $10 \%$ and not higher than $95 \%$; if a deposit contain more than $50 \mathrm{wt}$ \% of gravel material, it is referred to as gravel-and-sand deposit; at content of more than $5 \%$ of boulders it is referred to as bouldergravel—sand deposit.

Marketable products of the quarries developing the considered mineral deposits are sand, gravel, boulders and sand-and-gravel mix.

Gravel and boulders of the considered deposits vary highly in terms of their petrographic and strength composition. It refers not only to different deposits but, as a rule, to different gravel fractions of one and the same deposit (Lopatnikov \& Tedeev, 2007).

In terms of origin the sand deposits are classified as alluvial, old alluvial, true glacial, fluvioglacial, marine and lake deposits. The most widely spread are alluvial, old alluvial, and fluvioglacial deposits. Generation of the first two common types of deposits is related with the actions of rivers and periodic flows. Fluvioglacial deposits are the result of action of glaciers, or, to be more exact, glacial melt waters. Fragmentary material of deposits consists mainly of three type of rocks: volcanic (effusive), sedimentary, and mixed rocks.

Alluvial and old alluvial deposits, formed by mountain rivers, contain high percentage of large fragments: gravel and boulders. Deposits of lowland rivers with even flow contain fine fragmentary material: sand, especially in their lower course. Deposits of this type are in the shape of beds and lenses of wide extension.

Fluvioglacial deposits usually have the shape of eskers and kames. Eskers are narrow ridges with bottom and top width of 50-150 $\mathrm{m}$ and $5 \mathrm{~m}$, respectively, with the height of 15-50 m, 
spreading to the distance of several hundreds of meters, sometimes tens and even hundreds of kilometers. Kames are hilly glaciofluvial deposits with the slopes up to 45 degrees formed of gravels, sands and sand clays with horizontal and diagonal layers.

True glacial deposits have the shape of hills of longitudinal oval contours with the length up to several kilometers, width from several hundreds of meters to several kilometers, height of several tens of meters, formed by sand, gravel and boulder fractions of rocks (Shpanskiy \& Buyanov, 1996).

Existence of water bearing level in sand deposits, which separates the working thickness into dry and flooded portions, as well as technical parameters of handling equipment stipulate the sequence of separation of working thickness into production levels.

The bottom of lower bench of dry thickness of deposit is placed at $0.5 \mathrm{~m}$ above the level of ground waters aiming at creating of safety bedding above water bearing horizon.

One of the methods of cost reduction of mining of building sand is the usage of noncommercial reserves, the development of which can be implemented by application of up-to-date equipment and flowcharts of mining operations.

Therefore, determination of optimum mining parameters of flooded sands at quarries, supplying this feedstock to the companies of St. Petersburg, aiming at cost reduction of the feedstock mining is an urgent researching problem.

\section{METHODS}

Aiming at revealing of technological peculiarities of development of flooded sand deposits of Leningrad Region we analyzed available published data and project documentation of mining companies which develop flooded sands and supplying this feedstock to enterprises of St. Petersburg and Leningrad Region; thus, we established mining and geological peculiarities of the considered deposits.

The relief of Leningrad Region was formed in Quaternary period as a consequence of four glaciations and subsequently alternating interglacial epochs (Ulanov, 2007), thus, sand deposits occur in major part of the Region. Climate of the Region is Atlantic and continental climate, which stipulates comparatively mild winter with frequent thaws and lukewarm summers. Average annual amount of precipitations is in the range of $600-700 \mathrm{~mm}$, their maximum amount falls mainly in summer and autumn. In winter the precipitations are in the form of snow, constant snow cover exists generally from the late November to late April.

Deposits of quartz sands in Tosno District of Leningrad Region are currently the most promising for development due to construction of Moscow- St. Petersburg Federal highway.

The level of ground waters at these deposits are higher than $40 \mathrm{~m}$, the ground waters form single and consistent water bearing horizon, which separates the deposit working thickness into dry and flooded parts.

Sands of the deposits in Vyborg District of Leningrad Region are presented mainly by fluvioglacial formations, the lower part of the sand deposits is mainly flooded, water retaining stratum consists of granite, underlying quaternary deposits. The deposits are located in favorable transport conditions, since a wide network of local and federal motorways exists in this area.

In terms of physico-mechanical properties the deposits of Vyborg District are comprised mainly of loose non-coherent rocks (sands of working thickness), as well as of coherent and weakly coherent ores (clays, sand clays, clay loams, soil).

Sand quarries in Vsevolozhsk District of Leningrad Region are the major suppliers of this feedstock to the enterprises of St. Petersburg. The reserves are associated mainly with the thickness of quaternary glacial deposits, they are comprised of sands, sand clays, and clay loams.

Hydrogeological conditions of the deposit are characterized with the absence of steady ground water bearing horizon. Ground waters are phreatic, ground waters are recharged by atmospheric precipitations, water retaining stratum is comprised of clay loans and clays.

\section{RESULTS}

The performed analytical review of operation of mining companies developing flooded sand deposits in Leningrad Region revealed major technological peculiarities of mining at the 
considered quarries.

Dry thickness is usually developed by means of quarry deepening by longitudinal passes with horizontal benches. The flooded portion is developed by single bench without quarry deepening.

Mining complex of quarry operation is comprised of excavation and shipment of deposit mineral, transportation of mined product, development of deposit flooded thickness and transportation of hydraulic mix to depositing sites, as well as formation and development of depositing sites.

Development of flooded thickness should be performed by single bench to bottom boundary of calculating limit of reserves including dry thickness mining.

The main quarry machinery developing flooded sand deposits of Leningrad Region are as follows:

a) Hydraulic back shovel excavators are usually applied for mining at dry thickness of mineral deposits;

b) Floating dredges are are applied for mining at flooded thickness of deposits;

c) Crawler dozers are used for formation of depositing sites and waste dump and waste dump.

Mining operations at dry thickness and overburden removal are usually performed using cyclic flowchart with upward digging by hydraulic excavators.

Preparation of minerals for excavation is not required excluding winter periods. When ground is frozen to the depth of more than $40 \mathrm{~cm}$ the frozen layer should be loosened. This can be performed by excavator or ripper-dozer.

In accordance with "Specifications of

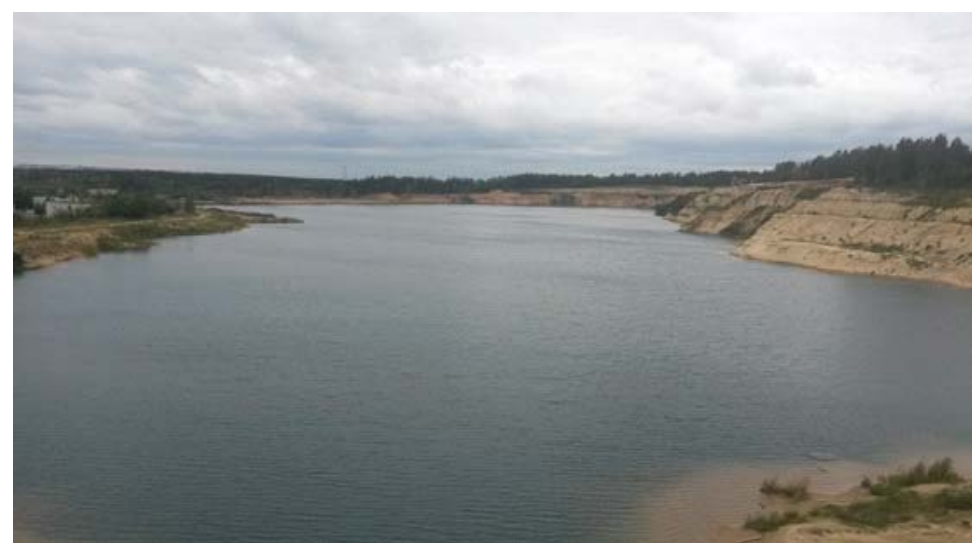

Fig. 1. Flooded Pugarevo quarry (Vsevolozhsk District, Leningrad Region)

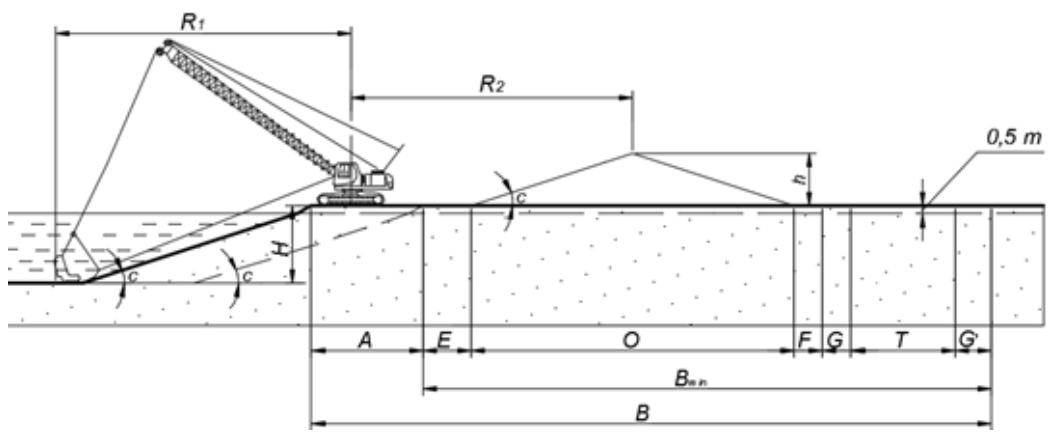

$\grave{A}$ - excavator pass width; $E, F$ - distance between excavator pass and lower embankment edge, lower embankment edge and road, respectively; $O$ - embankment bottom width; $G, T$ - width of shoulder and roadway, respectively; $B$ - width of working site; $B_{\min }$ - minimum width of working site; $h$ - embankment height; $H$ - digging depth; $\tilde{n}$ - angle of slope; $R_{1}, R_{2}$ - radii of digging and discharging of excavator, respectively.

Fig. 2. Elements of working site and quarry face of crawler dragline upon ore excavation from water 
designing of enterprises of non-ore building materials" and physico-mechanical properties of minerals the working slope angle of mining bench is $35^{\circ}$ for dry sands, and the working slope angle of mining bench for alluvial sands is about $60^{\circ}$.

Nominal list of quarry workers involved in development of flooded sand deposit is about 50 persons, including 8 engineers, operating shifts of about 20 persons, including up to 5 engineers and technicians.

Enriched sand is shipped by hydraulic excavators or front-end loaders into company's transporting vehicles or directly to vehicles of customers.

Approved by project capacity of quarries, developing flooded sand deposits of Leningrad
Region, is usually from 500 thousand to 1 million cubic meters of sand per year.

Flooded sands in terms of studied properties should meet the requirements of State standard 8736-93 "Sand for construction. Specifications" or Sanitary norm and regulations 2.05.02.85 "Automobile roads" depending on the scope of application, in terms of content of natural radionuclides sands should meet the requirements of State standard 30108-94 "Materials and items for construction”.

Operation mode of quarries - all year, 7 days per week, 2 or 3 shifts per day, sand excavation from submerged levels is planned on a seasonal basis in warm periods. While developing flooded

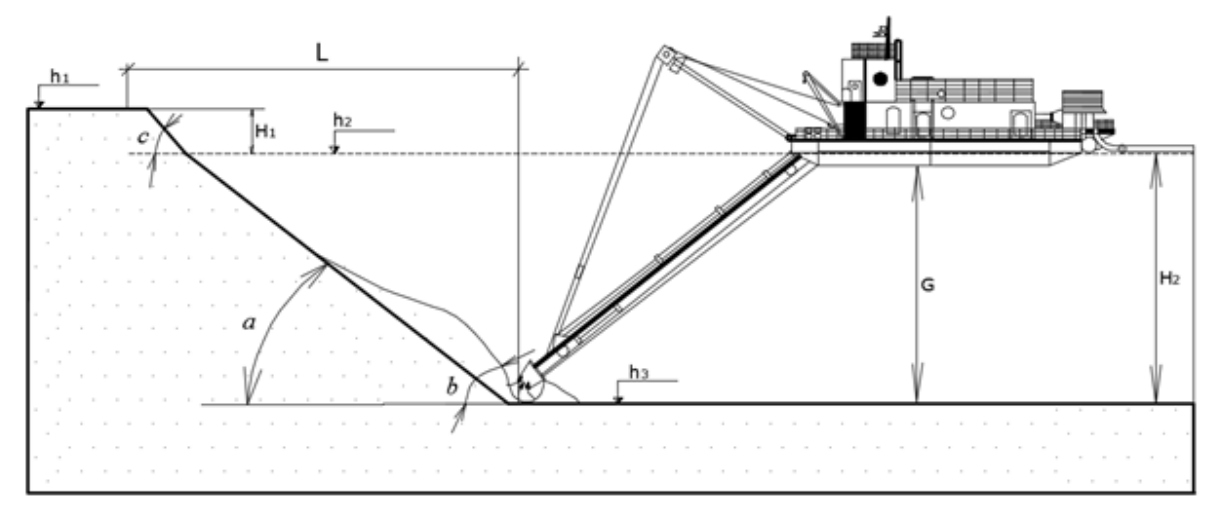

$a, b, c$ - angles of slope of submerged, operating and emerged benches, respectively; $h_{1}, h_{2}, h_{3}$, - height mark of emerged horizon, water level, and bottom, respectively; $L$ - permissible distance from emerged freeboard and place of slurry suction by dredge; $G$ - distance between the dredge hull and bottom (submerged) boundary of development; $H_{1}, H_{2}$ - height of emerged and submerged benches, respectively.

Fig. 3. Elements of submerged face of excavating floating dredge

sand deposits, located partially below ground waters and having positive temperatures even in winters, it is sufficiently easy to arrange all-season operation of mining complex, frozen rocks after their cutting and mining into underwater site are defrosted completely in one or two days and are transported to depositing sites (Babichev et al., 2006).

Taking into account that majprity of sand deposits of Leningrad Region, intended for development or already being developed, are presented by flooded mineral reserves, at the end of development the waste quarry area is a cavity partially filled with water (Fig. 1), which makes it possible to utilize the suspended fields for establishment of recreation sites, water supply facilities for agricultural purposes and other.

\section{DISCUSSION}

Development of flooded sand deposits is usually based on separation into dry and flooded portions. Flooded deposit portion is mainly developed by hydraulic method, sometimes back shovel excavators or draglines are applied in order to provide downward digging from flooded site (Ivanov \& Basov, 2013).

Prior to commencement of deposit 
development it is necessary to prepare surface area including forest clearing, stump clearing, moving of communications, buildings and structures, if any. At initial development stage of flooded sand deposit up to quarry commissioning mining uncovering operations are performed. These operations include opening to surface (trenches or pits) inside or outside of boundaries of quarry field, as well as creation of operation site in quarry.

While using excavators for development of sand deposits the quarry fields are opened by all types of permanent trenches: internal or external, stationary or sliding, separate, group or common.

In the case of deposits with flooded mineral bed and non-flooded thickness of dense overburden rocks, developed by cyclic digging and loading operations, overburden thickness (bench) is uncovered by inclined external trench with subsequent horizon preparation by working trench. Working thickness is uncovered by pioneer pit and at significant depth of emerged bench by internal inclined trench (decline) to water level in the area of dredge (Melkonyan et al., 2008).

Development of flooded sand deposits is mainly carried out using transport and specialized systems of development, overburden rocks are placed by dozers or front-end loaders in storage piles around the quarry periphery. Since the mined sand is a marketable product, dewatered sand is loaded into trucks and transported to place of destination.

Flooded thickness of sand deposits is usually developed by either of two flowcharts of mining operations: hydraulic mining by floating dredge, excavating of quarry sand by one-shovel excavators equipped with tools for digging from below excavator working level.

In the case of hydraulic mining it is proposed to use floating dredges of wide capacity range as major mining means and various tools for different development depths (Boutkevitch, 2004).

Dredges are intended for excavating of rocks from beyond water layer in natural and artificial water basins, and subsequent transportation to waste dumps, concentrating facilities or depositing sites (Glevickiy, 1988). Dredges operate in pits, quarries, rivers, lakes and seas (Dobrecov \& Ligockij, 2002). In mining industry dredges can be applied for uncovering and mining operations (Zelepukin et al., 1969). In construction and hydrotechnical operations they are used for creation of cavities, channels, aggradations, bed deepening (Harin \& Novikov, 1989).

In addition to dredges one-shovel excavators are used at deposits of mortar sand and sand-and-gravel mix; taking into account that these deposits can contain significant amount of boulders, then back shovel excavators are the most efficient equipment.

Hydraulic excavators and mechanical shovel excavators have small digging radii, thus, provision of safe angle of slope of flooded bench (according to the requirements of regulations the slope angle of working bench upon development of flooded sands is not higher than $18^{\circ}$ ) reduces possible depth of development. Mining of quarry sands should be reasonably performed by hydraulic one-shovel excavators with elongations of back-shovel type or draglines aiming at downward digging of rocks from underwater site.

The distance between sand deposits and trunk transmission lines, absence of required generating capacity and insignificant productive capacities of enterprises developing flooded sand deposits predetermine application of diesel digging and loading machinery at quarries (Ivanov, 2012).

The face of dragline operation is usually located at the bench edge or slope, and normal operation conditions are provided by edge or end cut located below the excavator working level (Berezovsky, 2010).

Figure 2 illustrates the main elements of working site and quarry face of crawler dragline upon mining operations from underwater site.

Therefore, taking into account the aforementioned, in order to develop flooded thickness of separate deposits of sand and sandand-gravel mix the most efficient is the use of diesel crawler excavators with draglines.

The main parameter of the considered development flowchart of flooded sand thickness is the digging depth of rocks from underwater site, its value depends on linear characteristics of the applied digging and loading machinery.

Since sand and sand-and-gravel mix are relatively loose materials, they can be mined from flooded thickness of these deposits by excavators with increased width of crawler track, which decreases surface pressure of machinery onto 
ground and sticking in soft grounds is prevented. Optimum length of operation area upon excavating of quarry sand from flooded site is determined on the basis shift productive capacity of mining excavator, cost of operation shift of automobile transport and loading capacity if trucks, average velocity of trucks, operation time of mining machinery in a shift, specific expenses of permanent and mining roads, capacity of developed thickness, as well as with accounting for bulk weight of mined minerals.

The main parameters of mining operations by a dredge are as follows:

a) width of dredge mining pass, which is determined on the basis of the distance between the milling cutter and the axis of working spud at completely finished truck stroke, as well as on the angle of dredge rotation around the axis of embedded spud (Nurok, 1985);

b) length of mining operation area;

c) dredge operation cycle and productive capacity.

Figure 3 illustrates the main elements of underwater mining site of floating dredge.

The length of dredge operation area in certain cases should be reasonably determined on the basis of inventory stock of hulls of floating slurry pipeline, in this case the length of operation area is determined by the length of dredge hull, length of a unit of floating slurry pipeline, available number of units of floating slurry pipeline, as well as by angle ball joints of floating slurry pipeline (Jaltaneñ \& Levanov, 2008).

The length of mining operation area upon development of flooded thickness of sand deposit should provide optimum transportation distance of rocks, as well as to create conditions for water drainage to depositing site. Economically efficient length of dredge operation area should be determined on the basis of minimum expenses for items effected by the length of dredge mining operation. The main cost items determined by the length of dredge mining operation are depreciation expenses for pump and pipeline equipment, expenses of fuel consumed by pump and transporting equipment, excess expenses of repair of pump and transporting equipment.

The time of total development of rocks from the face of one dredge operation site is determined by the amount of rocks, intended for mining on the basis of dredge operation capacity.

Dredge operation cycle is composed of the face development time and time required for dredge traveling to a new face.

Shift dredge operation capacity should be reasonably determined as follows ( $\mathrm{m}^{3} / \mathrm{shift}$ )

$$
Q_{\mathrm{d}}=Q_{\mathrm{t} . \mathrm{d}} \cdot K_{\mathrm{e}}\left(T_{\mathrm{c}}-N_{\mathrm{z}} \cdot T_{\mathrm{dr}}\right)
$$

where $Q_{\mathrm{t} . \mathrm{d}}$ is the dredge potential production capacity $\left(\mathrm{m}^{3} / \mathrm{min}\right) ; K_{\mathrm{e}}$ is the operation factor of dredge in a shift, $\mathrm{T}_{\tilde{\mathrm{n}}}$ is the time of continuous dredge operation in a shift, $N_{\mathrm{z}}$ is the number of cycles of dredge operation in a shift, $T_{\mathrm{dr}}$ is the average time of dredge repositioning to a new position of mining operations in quarry.

The shape of underwater portion of face is a sector formed by minimum and maximum radii of dredge suction, as well as by the radius of dredge working travel around the axis of embedded spud.

Rock amount $\left(\mathrm{m}^{3}\right)$, which should be mined from the face at on dredge site, is as follows:

$$
V_{\mathrm{f}}=B \cdot\left(R_{o}-R_{\min }\right) \cdot h
$$

where $B$ - is the dredge pass width (m); $R_{0}$ is the distance between the milling cutter and the axis of spud at completely finished truck stroke (m); $R_{\min }$ - is the minimum distance between the milling cutter and the axis of spud upon digging (m); $h$ is the height of developed bench (m).

Soil loss at the quarry bottom depends on the soil properties, flowchart of working travels and digging method, face height and dredge production capacity. Two major flowcharts of dredge working travels in quarry are distinguished: rope and spud-rope. The rope system is applied upon development of non-coherent poorly consolidated soils (sands, sand-and-gravel mixes). The spud-rope system is applied upon development of dense and consolidated soils (sand-and-gravel materials, clay loams, clays) using mechanical cutter. In practice of development of aggregates the excavating parameters are optimized on the basis of criterion of maximum productive capacity (Bagazeev \& Miljutin, 2010).

Separate excavation of overburden rocks and minerals can be performed by a single dredge in advance of uncovering operations (Kazakov, 2009). Shipment of sands from depositing sites is 
usually performed by hydraulic excavators with back shovel.

In the case of excavator development shipment of sands from dumps after their dewatering is performed by specialized equipment, in addition, it can be performed by dragline, which significantly reduces costs for purchasing of plant and equipment.

Mining of sand in the forests of Leningrad Region leads to cardinal alteration of environment, violation of protective, water regulating and other functions of forests (Navalikhin et al., 2013).

The main types of environmental impact upon development of quarries of mortar sands are as follows (Schepetova, 2014):

a) Withdrawal of natural resources (soils, water);

b) Air contamination with gaseous and dust substances;

c) Noise emission;

d) Modification of terrain relief, hydrogeological conditions of construction site and adjacent areas;

e) Contamination of land allocation with wastes and effluent waters;

f) Modification of social conditions for population and others.

At present there are numerous technological and special measures aimed at decrease in negative impact of development of flooded sand deposits on environment.

\section{CONCLUSIONS}

On the basis of the performed analysis of peculiar features of development of flooded sand deposits of Leningrad Region we determined the particular characteristics of major procedures of two technological flowcharts of feedstock extraction using hydraulic mining and excavators.

Qualitative properties of alluvial sand produced by hydraulic mining using floating dredges are superior to those of quarry sand produced by excavating due to the absence of dust and clayish particles.

Particle sizes of produced sand also determine its future cost because this parameter influences on the properties of building materials manufactured on the basis of this feedstock
(Gulyaev \& Ganike, 2012).

While designing development of flooded sand deposits it is necessary to take into account that the cost of alluvial sand is higher than that of dry quarry sand: this results in higher profits of mining company. Higher demand for alluvial sand for production of concrete and road filling due to its quality expands markets of quarry products from sand deposits with flooded thickness.

Selection of optimum parameters of mining operations using dredges already at the designing stage of development of flooded sand deposit makes it possible to carry out the quarry operations in efficient and safe manner.

One of the main drawbacks of hydraulic excavation using floating dredges consists of more complicated arrangement of mining operations in comparison with sand production by excavators.

\section{REFERENCES}

1. Babichev, N.I., A.E. Dvorenko, A.Ju. Filchukov, The new ejector dredges for extraction of sand and gravel mixtures. The Mountain information and analytical bulletin, 2006; 4: 341-346

2. Bagazeev, V.K., I.A. Miljutin, Physical and mechanical study of losses in mining of sand and gravel dredges. Proceedings of the universities. Mining Journal, 2010; 3: 21-26.

3. Berezovsky, S.N., The decision of the problem of deficiency of sand and sand-gravel in Mogilev area by rational working out of open-cast mines. Vestnik Belarusian - Rassian university, 2010; 4(29): 122-127.

4. Boutkevitch, G.R., Problems of water-bearing deposits of nonmetallic minerals. Mining Journal., 2004; 5: 27-31.

5. Dobrecov, V.B., D.N. Ligockij, Hydromechanization and operation of subsea fields . SPb: St. Petersburg Mining Institute, 2002.

6. Gilev, A.V., Mechanized complex for the extraction of construction materials on the watered fields. Mining Equipment and Electromechanics, 2008; 6: 18-20.

7. Glevickiy, V.I., Hydromechanization in transport construction. M.: Transport, 1988.

8. Gulyaev, V.T., S.V. Ganike, Influence the quality of sand on the properties of foam. Vologdin reading, 2012; 80: 35-36.

9. Harin, A.I., M.F. Novikov, Hydromechanization excavation works in construction. M.: Stroyizdat, 1989. 
10. Ivanov, V.V., Characteristics of development of water cut mass in deposits of sand and sand gravel mix. Mine mechanical engineering and machine-building, 2012; 3: 28-31.

11. Ivanov, V.V., T.S. Basov, Analysis of technological actions ensuring the rational development of waterencroached deposits of sand and sand-gravel mixture. Monthly scientific and methodological e-journal "Koncept”, 2013; 4(34): 2156-2160.

12. Jaltaneñ, I.M, N.I. Levanov, Reference jetting. M.: "The world mountain book", MGGU Publisher, Publisher "Mountain Book”, 2008.

13. Kazakov, V.A., Questions of improvement of quality of sand. The Mountain information and analytical bulletin, 2009; 12: 452-467

14. Lopatnikov, M.I., T.R. Tedeev, Sand and gravel deposits as a possible source of local durable rubble. Construction Materials, 2007; 5: 18-19.

15. Melkonyan, R.G., A.N. Efremov, P.M. Kandaurov, The technological scheme of development of deposits of quartz sand . Mining industry, 2008; 5(81), 68-71.

16. Navalikhin, S.V., P.M. Zurbenko, M.G. Starusev, State of the living ground cover on the waste sand quarry Roshchinsky forestry Leningrad region. Recent research trends of the XXI century: Theory and Practice: 2013; 205-210.

17. Nurok, G.A., Processes and technology of jetting open pit mining. Ì.: Nedra, 1985.

18. Peshkova G. Yu., The analysis of the market of non-metallic building materials: the main tendencies and perspectives. Electronic scientific journal "Corporate Governance and innovative economic development of the North: Bulletin of Research Center of Corporate Law, Management and Venture Investment of Syktyvkar State University”, 2014; 4: 53-64.

19. Schepetova, V.A., Estimation of the influence upon atmospheric air action on development deposits and mining building song in Penzenskoy area. Modern problems of science and education, 2014; 2: 16.

20. Shpanskiy, O.V., Ju.D. Buyanov, Technology and complex mechanization of production of non-metallic raw materials for the production of building materials. İ., Nedra, 1996.

21. Ulanov, V.A., Leningrad region: Did you know ? SPB . : Parity, 2007.

22. Zelepukin, N.P., L.M. Ravinskiy, A.I. Harin, Directory hydromechanic. Kiev: Budivelnik, 1969. 